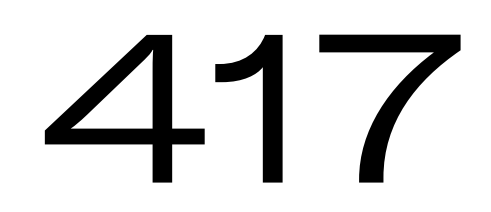

Júlio Castañon Guimarães 


$$
\text { Júlio }
$$

Castañon

Guimarães 


\section{Então, e cinema}

1.

no correr do tempo

em que se vão embaralhando

as cenas como os fios

das tramas emaranhadas

e inesperados todos os personagens

ou quando: desconecte-se o texto da imagem

tudo mostra de que jeito o que está ali

são peças a que sempre só falta as concatenarmos

2.

as narrações parece que um dia tendem a se desfazer

3.

o movimento de um deslocar-se pelo quadro

mas se uma névoa invade toda a imagem

e cinzas sob cinzas nos ensinam a indistinção

então a hipótese de uma linha do deslocamento

que atravessa a cena o silêncio da cena

e se enterra memória adentro 


\section{Calendário}

hoje como ontem

talvez não valesse nem atentar

ao acúmulo de ruínas

que um ou outro tremor

num desnorte de sinais

mas se poderia quem sabe

que se desenredar

em meio a tempos

confundidos ao arrepio dos dias

e desenvolto um fio no ar

e perdido quase

que talvez

vestígio

entre alguns rascunhos de arranjos

JÚLIO CASTAÑON GUIMARÃES é poeta, tradutor, pesquisador e doutor em letras pela Universidade Federal do Rio de Janeiro. Autor de, entre outros, Poemas [1975-2005] (7Letras/Cosac Naify, 2006), Se dispersão (7Letras, 2017) e Em viagem (Tipografia do Zé, 2017). Recentemente, publicou a tradução integral de As flores do mal, de Baudelaire (Companhia das Letras, 2019). 